\title{
Researching the World of Work
}


This page intentionally left blank 


\title{
Researching the World of Work
}

\section{Strategies and Methods in Studying Industrial Relations}

\author{
Edited by Keith Whitfield \\ and George Strauss
}


All rights reserved. Except for brief quotations in a review, this book, or parts thereof, must not be reproduced in any form without permission in writing from the publisher. For information, address Cornell University Press, Sage House, 512 East State Street, Ithaca, New York 14850.

First published 1998 by Cornell University Press

Printed in the United States of America

Library of Congress Cataloging-in-Publication Data

Researching the world of work : strategies and methods in studying industrial relations / Keith Whitfield and George Strauss, editors.

p. $\mathrm{cm}$.

Articles by contributors recruited by the Research Methods Study Group of the International Industrial Relations Association (IITA). Includes bibliographical references and index.

ISBN 0-8014-3290-1 (alk. paper). — ISBN 0-8014-8549-5 (pbk. : alk. paper)

1. Industrial relations-Methodology. I. Whitfield, Keith. II. Strauss, George, b. 1923. HD6961.R37 1998

$331^{\prime} .07^{\prime} 2-\mathrm{dc} 21$

Cornell University Press strives to use environmentally responsible suppliers and materials to the fullest extent possible in the publishing of its books. Such materials include vegetable-based, low-VOC inks and acid-free papers that are recycled, totally chlorine-free, or partly composed of nonwood fibers.

Cloth printing $\quad 1098876 \quad 6 \quad 543321$

Paperback printing $\quad \begin{array}{llllllllll}10 & 9 & 8 & 7 & 6 & 5 & 4 & 3 & 2 & 1\end{array}$ 


\section{Dedicated}

to the memory of

Jan Bruins 
This page intentionally left blank 